\title{
Deep Neck Infection due to Traumatic Intubation: A Case Report
}

\author{
Travmatik Entübasyona Bağlı Gelişen Derin Boyun Enfeksiyonu: Olgu Sunumu
}

Gökhan Yalçıner, Ahmet Kutluhan, Kazım Bozdemir, Akif Sinan Bilgen, Behçet Tarlak

Department of Otolaryngology, Ankara Atatürk Training and Research Hospital, Ankara, Turkey

\begin{abstract}
In this article we present a patient who developed deep neck infection secondary to a difficult intubation. We discuss the potentially life-threatening nature of deep neck infections by the spreading of infection along cervical planes.
\end{abstract}

Keywords: Neck, infection, intubation

Received: 01.02.2012 Accepted: 23.10.2012

\section{ÖZET}

Bu makalede, zorlu entübasyona ikincil olarak gelişen derin boyun enfeksiyonunu sunuyoruz. Servikal planlar boyunca yayılan, hayatı tehdit eden derin boyun enfeksiyonlarının yapısını tartıştık.

Anahtar Kelimeler: Boyun, enfeksiyon, entübasyon Geliş Tarihi: 01.02.2012 Kabul Tarihi: 23.10.2012

\section{Introduction}

Although the new and widespread use of antibiotics has dramatically reduced the incidence and mortality of deep neck space infections, they still are unique among infectious diseases for their versatility and potential for severe complications $(1,2)$. Deep neck infections are defined as infections that spread along the facial planes and spaces constituted by multiple layers of cervical fascia encasing the contents of the neck $(1,3)$. In the era before antibiotics, $70 \%$ of deep neck infections (DNI) resulted from the spread of pharyngeal and tonsillary infections (2). More recent trends include a decline in the number of DNIs caused by pharyngitis or tonsillitis, and a relative increase in cases of related odontogenic infections (1). Other causes include trauma, surgical trauma, oesophageal perforation, laryngopyocele, infected branchial cleft and thyroglossal duct cysts.

Despite the gains in the era of antibiotics and diagnostic techniques, DNIs still remain life threatening. A delay in the diagnosis or inadequate treatment can lead to dire complications such as mediastinitis, airway compromise, and jugular vein thrombosis $(1,3)$. Aggressive monitoring and management of the airway is the most urgent and critical aspect of care, followed by appropriate antibiotic coverage and surgical drainage, when needed (1).

In the current literature, we found only one case of DNI due to intubation trauma so we decided to present this unusual case who had widespread neck infection due to a difficult intubation in a different hospital (4).

\section{Case Report}

A 51 year old man was admitted to our hospital emergency department complaining of swelling on the neck and a sore throat. His medical history included a lumbar disc operation on the previous day and he had been told that he had undergone a difficult intubation.

On physical examination there was significant swelling, crepitation and tenderness on the neck but no erythema (Figure 1). Endoscopic examination of the upper airway showed slight epiglottic oedema and diffuse oedema on the right side of the larynx. The piriform sinus was obliterated by swelling. However, we could not see any laceration on the larynx and hypopharynx. The 
airway was sufficient for breathing. His body temperature was normal and his white blood cell count was $10.8 \mathrm{~K} / \mathrm{uL}$. Ultrasonographic examination of the neck revealed diffuse air columns subcutaneously and between the muscles but no pus or liquid collections. The patient was hospitalised, oral feeding was stopped, and intravenous liquid was ordered.

On the following day, the patient's body temperature was $38^{\circ} \mathrm{C}$. The neck and thorax computed tomography (CT) revealed air on the neck, paratracheal and anterior mediastinal areas but no liquid or pus collection (Figure 2a, b). The patient was referred to the infection department and imipenem-cilastatin 4×500 mg and total parenteral nutrition was started.

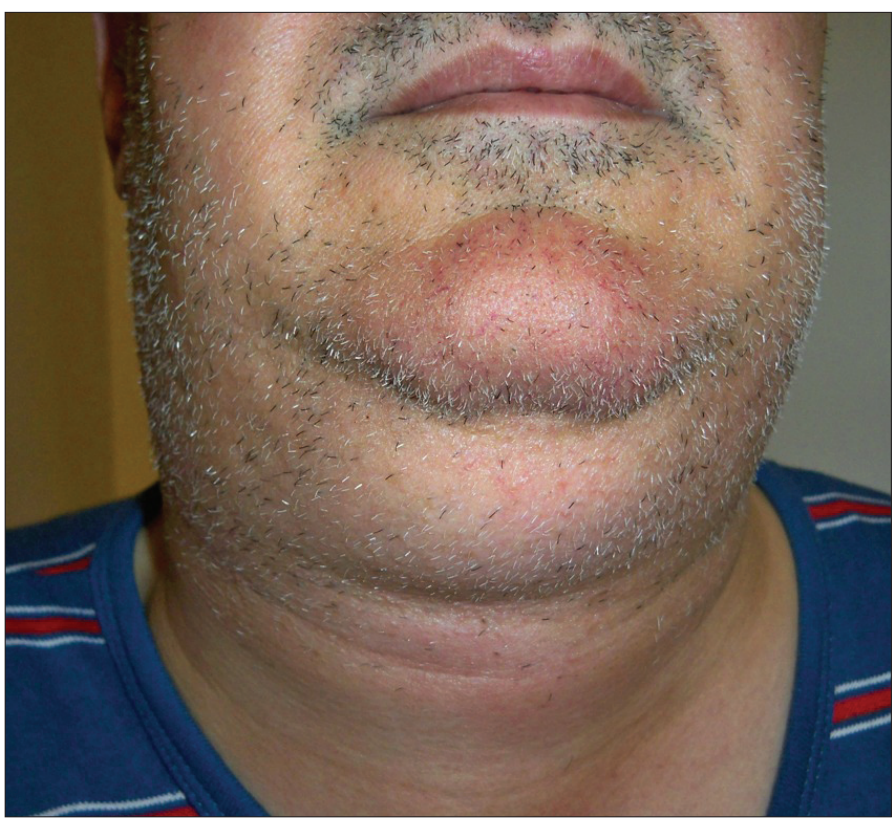

Figure 1. Picture of the patient on the first day

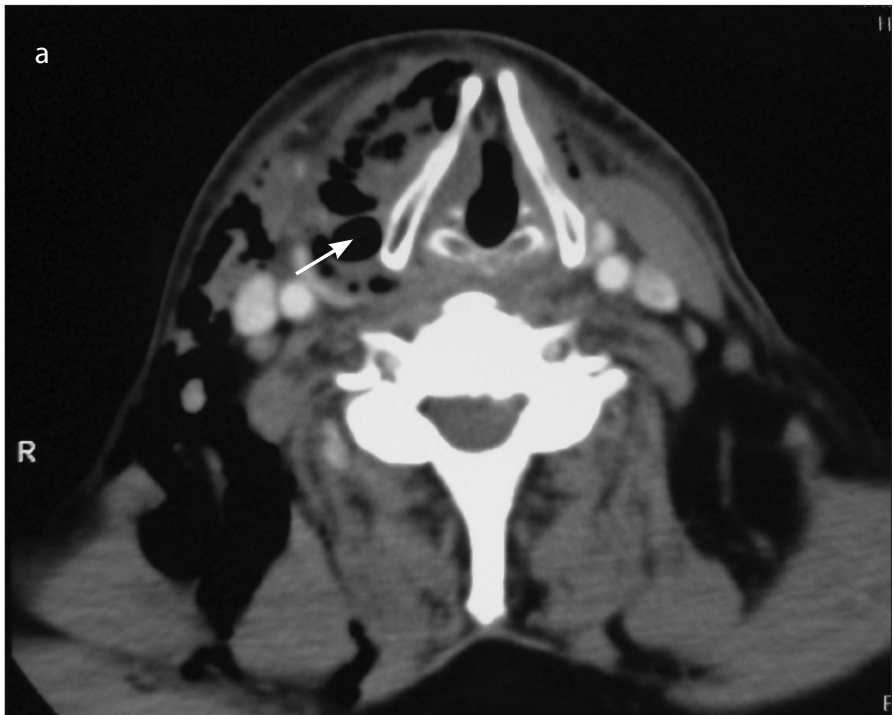

On the fifth day, the swelling of the neck was persisting and the needle aspiration revealed pus from the pre-tracheal region. The material was cultured and the neck was explorated from a pre-tracheal region by a horizontal incision. Nearly 50 cc of pus was drained and a Penrose drain was inserted.

During the following days, drainage of pus continued, gradually decreasing for five days. There was no fever on the following days. Pseudomonas organism was found on the culture and imipenemcilastatin was continued for 14 days. On the tenth day, with a decrease in oedema of the larynx, we decided to start oral feeding. Before starting oral feeding, in order to investigate the presence of hypopharyngocutaneous fistula, the patient was given methylene blue stained water orally several times and was checked for stained drainage. When no fistula signs were observed, oral feeding started. On the $15^{\text {th }}$ day the patient was discharged from hospital with full recovery.

\section{Discussion}

DNIs are defined as infections that spread along the fascial planes and spaces of the head and neck (5). DNIs are potentially life-threatening as a result of their descending spread along the cervical fascia planes toward the mediastinum and development of sepsis after thrombophlebitis of the internal jugular vein (6). Therefore, the relationships of these different layers are important for understanding DNIs because these spaces can communicate freely with one other (7). The superficial fascia extends from the neck to the thorax, shoulders and axilla (7). Deep to the superficial fascia lays the deep cervical fascia, which consists of three layers: the superficial layer, the middle layer and the deep layer. The deep layer is made up of prevertebral and alar layers (7). The alar layer extends from the base of the skull to the posterior mediastinum (7). Because of the fascial anatomy in the lower face and neck, many potential spaces exist where infections, cellulites and abscesses can spread by continuity (7).

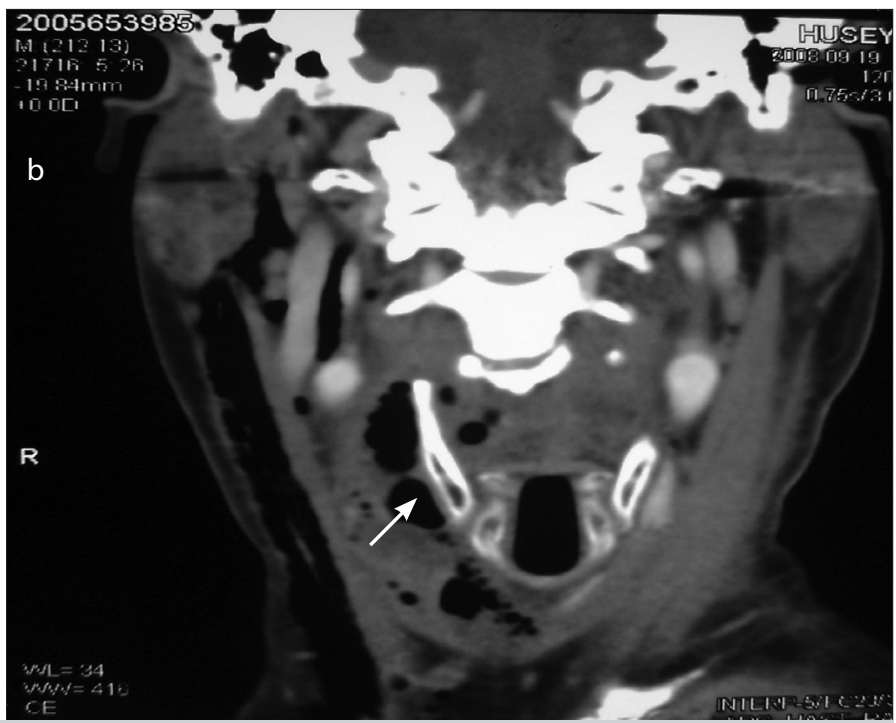

Figure 2a, b. Cervical CT (axial-coronal) showing air columns between the neck tissues 
The most common cause of DNIs has been reported to be odontogenic infections in different series $(3,5,8)$. Other causes include tonsillary and pharyngeal infections and trauma (1). In our case the difficult intubation probably lacerated the pharyngeal wall causing the oropharyngeal microorganism to enter the neck spaces. There are also several reports in the literature of tracheal rupture and subcutaneous emphysaema due to difficult or emergent intubation $(4,6)$.

The bacteriologic pattern of DNIs is usually polymicrobial, including aerobes, microaerophilics and anaerobes (8). The most common bacterial species are the group A streptococci and the anaerobic Bacteriodes groups (9). These organisms are members of the normal oropharyngeal flora. In our case, the causative microorganism was pseudomonas aeroginosa which has not been reported frequently in the literature.

History, physical examination, laboratory work and diagnostic imaging each provide important clues when assessing a patient for DNI (4). However, initial evaluation of the airway is the first priority and any signs of respiratory distress or impending airway compromise should be immediately and aggressively managed $(1,10)$. Risk factors including diabetes mellitus, HIV infection, steroid therapy, chemotherapy and other sources of immune disfunction should be identified early and appropriately managed to minimise complications (1). In our case there were no risk factors or additional diseases and the airway was sufficient. Tracheotomy was not necessary.

Appropriate management of DNIs is highly dependent on the location of deep neck involvement and diagnostic imaging is essential in nearly every case (1). Contrast enhanced CT scans, ultrasound and magnetic resonance imaging scans are all very useful in monitoring DNIs $(1,3,5)$. For early detection of impending complications such as mediastinitis, CT examination is also highly diagnostic (3). The observation of air columns within the spaces of neck tissues on CT confirmed the presence of trauma in our case.

Every patient who has a DNI should be given initial empiric antibiotic therapy until culture and sensitivity results are available (10). DNIs cannot be managed by antimicrobial therapy alone (9). These infections require surgical debridement of dead tissue and drainage of pus collections $(1,3,5,9)$.

Even improvements in the diagnostic and therapeutic approaches are not sufficient to prevent the significant morbidity and mortality of DNIs. Early diagnosis as well as aggressive antibiotic therapy covering both aerobic and anaerobic bacterial spectra and early surgical intervention have great importance in the treatment of DNIs.

An investigation for fistula should be carried out before oral feeding is started in cases of DNIs related to hypopharyngeal areas, as in our case. Investigations for fistula can be carried out with methylene blue stained water ingestion, as was done in our case, or by radiology with the ingestion of radioopaque material. Barium containing opaque materials should not be used for these purposes because they are toxic to neck tissues (11). In searching for lacerations, flexible fibre optic endoscopes should be used carefully so as not to cause additional mucosal trauma.

\section{Conclusion}

DNIs still remain life threatening and a delay in the diagnosis or inadequate treatment can lead to life threatening complications. Besides the well-known causes of DNI such as odontogenic infections, surgical trauma, trauma, and oesophageal perforation, it must be kept in mind that although rare, DNI can be caused by traumatic intubation as in our case.

\section{Conflict of interest}

No conflict of interest was declared by the authors.

\section{References}

1. Vieira F, Allen SM, Stocks RM, Thompson JW. Deep neck infection. Otolaryngol Clin North Am 2008; 41: 459-83. [Crossref]

2. Scott BA, Stiernberg CM, Driscoll CM, Driscoll HC. Deep Neck Space Infection. in: Bailey BJ, Editor. Pillsburg HC III Philadelphia: Lipincott-Ravel; 1998.p.819-35.

3. Kinzer S, Pfeiffer J, Becker S, Ridder GJ. Severe deep neck space infections and mediastinitis of odontogenic origin: clinical relevance and implications for diagnosis and treatment. Acta Otolaryngol 2009; 129: 62-70. [Crossref]

4. Orta DA, Cousar JE, Yergin BM, Olsen GN. Tracheal laceration with massive subcutaneous emphysema: a rare complication of endotracheal intubation. Thorax 1979; 34: 665-9. [Crossref]

5. Eftekharian A, Roozbahany NA, Vaezeafshar R, Narimani N. Deep neck infections: a retrospective review of 112 cases. Eur Arch Otorhinolaryngol 2009; 266: 273-7. [Crossref]

6. Marty-Ané $\mathrm{CH}$, Picard E, Jonquet O, Mary H. Membranous tracheal rupture after endotracheal intubation. Ann Thorac Surg 1995; 60: 1367-71. [Crossref]

7. Marcus BJ, Kaplan J, Collins KA. A case of Ludwing angina: a case report and review of the literature. Am J Forensic Med Pathol 2008; 29: 255-9. [Crossref]

8. Huang TT, Liu TC, Chen PR, Tseng FY, Yeh TH, Chen YS. Deep neck Infection: analysis of 185 cases. Head Neck 2004; 26: 854-60. [Crossref]

9. Uram J, Hauser MS. Deep neck and mediastinal necrotizing infection secondary to a traumatic intubation: report of a case. J Oral Maxillofac Surg 1988; 46: 788-91. [Crossref]

10. Osborn TM, Assael LA, Bell RB. Deep Space neck infection: principles of surgical management. Oral Maxillofac Surg Clin North Am 2008; 20: 353-65. [Crossref]

11. Bell RB, Osborn T, Dierks ES, Potter BE, Long WB. Management of penetrating neck injuries; a new paradigm for civilian trauma. J Oral Maxillofac Surg 2007; 65: 691-705. [Crossref] 